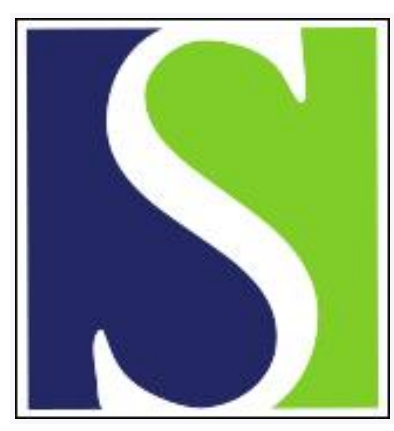

Scand J Work Environ Health 1977;3(2):91-99

https://doi.org/10.5271/sjweh.2785

Issue date: Jun 1977

Psychological function changes among house painters.

by Hane M, Axelson O, Blume J, Hogstedt C, Sundell L, Ydreborg B

Key terms: brain damage; hemoglobin; hemoglobin concentration; house painter; painter; psychological function; psychological function test; solvent; work environment

This article in PubMed: www.ncbi.nlm.nih.gov/pubmed/882861

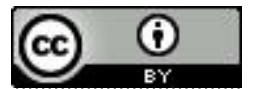




\title{
Psychological function changes among house painters
}

\author{
by MONICA HANE, Ph.D., OLAV AXELSON, M.D., JAN BLUME, \\ CHRISTER HOGSTEDT, M.D., LENNART SUNDELL, M.D., \\ and BERIT YDREBORG ${ }^{1}$
}

\begin{abstract}
HANE, M., AXELSON, O., BLUME, J., HOGSTEDT, C., SUNDELL, L. and YDREBORG, B. Psychological function changes among house painters. Scand. $j$. work environ. \& health 3 (1977) 91-99. Nonspecific complaints such as fatigue, partial amnesia, loss of appetite, etc., have been reported by house painters and could be effects of occupational exposure to solvents. A random sample of union-affiliated house painiters was compared for a number of parameters and psychological test results with a gnoup of industrial workens having a corresponding age distribution. The groups proved to be on par in relevant background variables. A simple health check did not reveal any cornelates to the subjective complaints, except for a somewhat lower hemoglobin concentration among the house painters. However, the painter group had significantly lower mean scores on psycholagical tests measuring intellectual capacity and psychomator coordination than the reference group of industrial workers. The painter group also had significantly lower performances than expected on the memory test and the reaction time test. A discriminant analysis of indicaitors of change, as derived from psychological tests, was carried out, and a point biserial correlation of 0.35 was obtained between the discriminant function and the dichotomous exposure variable defined by group affinity. Furthermore a study based on clinical patients, i.e., another body of data, indicated reasonable diagnostic validity for this discriminant function. Although no correlations were found within the painter group between exposure ("painter years") and the indicators of function change, the results indicate an effect of the work environment on health.
\end{abstract}

Key words: brain damage, hemoglobin concentration, psychological function tests, solvents, work environment.

Previously, disturbances in memory, thinking, and affect have been reported among workers exposed to trichloroethylene, carbon disulfide and toluene (20). Hänninen (12) found that a group of workers exposed to carbon disulfide, but without clinical signs of poisoning, had significantly lower scores on tests measuring speed, vigilance, manual dexterity,

1 Department of Occupational Medicine, Regional Haspital, Örebro, Sweden.

Reprint requests to: Dr. Monica Hane, Department of Occupational Medicine, Regional Hospital, S-701 85 Örebro, Sweden. and general intelligence than an unexposed reference group. Another exposed group showing clinical signs of poisoning performed still worse than the other exposed group. In a study of workers exposed to different types of solvents, Lindström (17) found that the exposed group had some impairment on all psychological tests, the greatest changes occurring on tests measuring visual perception and manual dexterity. Hänninen concluded in her study (12) that psychological tests are more sensitive in detecting early disturbances of the central nervous system due to solvents than traditional medical examinations. 
Since house painters complaining of extreme fatigue, impaired memory, loss of appetite, and diffuse chest pain have appeared as patients, we have initiated further studies on the possible health effects of their work environment.

\section{MATERIAL AND METHODS}

In 1973, a sample of house painters with more than 5 years of experience was randomly drawn from the trade union register in the county of Örebro. Their ages ranged from 25 to 60 years (mean 42.5, SD 11.4). These painters were compared in a number of psychological tests to a group of industrial workers with a matched age distribution ( \pm 2 years) who were unexposed to solvents. The reference group came mainly from a wire producing industry, a printing office (solvent exposed workers excluded) and a stone crusher, all in the county of Örebro.

In addition to psychological testing the subjects underwent a penetrating interview concerning prior professional exposure to solvents. In the interview the number of years as a painter was estimated for each individual. In Sweden the trade of "painter" includes that of wallpaper hanger, and, by correcting for these periods of nonexposure, we were able to create a rough exposure index of "painter years," which presumably should be a more adequate measure of exposure than the crude number of occupational years as a painter. The "painter years" ranged from 4 to 42 years (mean 14.2, SD $6.7)$.

It can be estimated that the painters had been exposed to several hundred parts per million of hydrocarbon solvents, as such concentrations seem to be common (13). The exposure to paint pigments is probably of minor importance, and, in Sweden at least, exposure to lead is rather unusual because of the special regulations for the utilization of lead pigments in paints.

A health interview, based on a questionnaire concerning subjective symptoms like tiredness and impaired memory, was also included in the study along with a traditional medical examination, i.e., checking blood pressure, hemoglobin concentration, sedimentation rate, serum transaminases, and respiratory function (table 1).

\section{Psychological test battery}

The test battery utilized in this study is generally used at psychiatric and neurological clinics in Sweden in diagnosing organic brain damage. It covers those

Table 1. Means of the medical variables for the painter and reference groups.

\begin{tabular}{|c|c|c|c|}
\hline Medical variable & $\begin{array}{c}\text { Painters } \\
\mathrm{n}=52\end{array}$ & $\begin{array}{c}\text { Referents } \\
\mathrm{n}=\mathbf{5 2}\end{array}$ & $\begin{array}{l}\text { Two-tailed p } \\
\text { values from } \\
\text { Studient's } \\
\text { t-test }\end{array}$ \\
\hline Blood pressure, systolic ( $\mathrm{mm} \mathrm{Hg}$ ) & 138.0 & 137.3 & 0.79 \\
\hline Blood pressure, diastolic ( $\mathrm{mm} \mathrm{Hg}$ ) & 85.5 & 88.6 & 0.10 \\
\hline Hemoglobin concentration $(\mathrm{g} / \mathrm{l})$ & 151 & 160 & 0.01 \\
\hline Sedimentation rate $(\mathrm{mm})$ & 11.6 & 9.3 & 0.40 \\
\hline Height $(\mathrm{cm})$ & 176.8 & 175.2 & 0.20 \\
\hline Weight (kg) & 78.8 & 78.1 & 0.76 \\
\hline S-ASAT (asparat-amino-transferas) ( $\mu \mathrm{kat} / \mathrm{l})$ & 0.67 & 0.73 & 0.21 \\
\hline S-ALAT (alanin-amino-transferas) $(\mu \mathrm{kat} / \mathrm{l})$ & 0.55 & 0.54 & 0.96 \\
\hline \multicolumn{4}{|l|}{ Spirometry ( $\%$ of normal values) } \\
\hline Vital capacity & 97.7 & 97.1 & 0.79 \\
\hline FEVa $(\mathrm{s})$ & 105.1 & 105.2 & 0.96 \\
\hline FEV $\%$ & 107.4 & 108.4 & 0.57 \\
\hline
\end{tabular}

a $\quad \mathrm{FEV}=$ Forced expiratory volume. 
Table 2. Hemoglobin concentrations of the painiter and reference groups in relation to smoking habits.

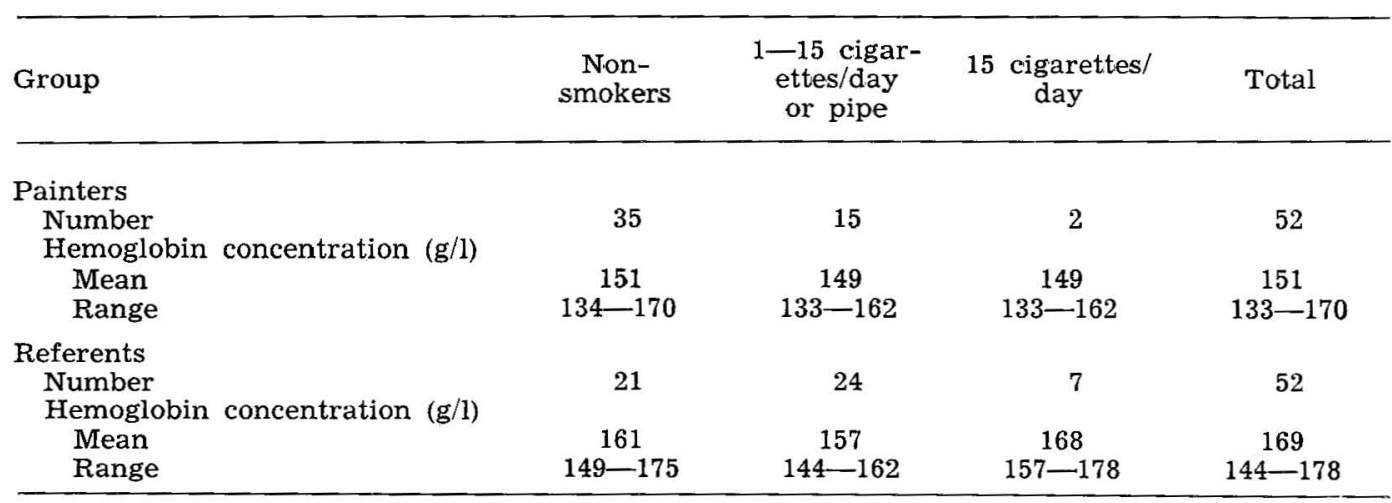

psychological functions for which impairment has been demonstrated in earlier studies of workers exposed to solvents $(12,14,17)$. When this battery of tests is administered to individual patients for diagnostic purposes with regard to diffuse organic brain damage, the discrepancy between "hold tests" and "nonhold tests" is used. Thus it is assumed that verbal ability is fairly resistant (a hold test) and can be used as an indicator of the intellectual predamage level, while the other functions measured by the battery (nonhold tests) are known to be impaired more quickly than verbal ability in cases of diffuse organic brain damage $(21,24)$. This principle has been criticized (16), but some kind of estimation of prior intellectual capacity has to be used when isolated cases are being considered, and there are few alternatives. When groups are being studied by means of psychological tests, it is beneficial if the tests chosen also serve further individual diagnostics. The tests used in our study can be found in table 3 , where also the psychological function measured by each test and references to the respective manual are given.

\section{Statistical methods}

Since all variables turned out to have fairly symmetrical distributions, the means were compared by the Student's t-test throughout. Also a stepwise multiple discriminant analysis (7) was undertaken so that the weighted sum of the indicators of intellectual impairment with the highest correlation to dichotomized exposure (i.e., exposed versus nonexposed) could be obtained.

\section{RESULTS}

\section{Evaluation of background variables}

Valid conclusions from cross-sectional studies presuppose that the exposed and the nonexposed are comparable in respects other than exposure and its possible effects. Ascertaining the comparability was possible since, starting in 1943, all Swedish men are tested for general intelligence when they enter the military service. Although the main purpose of that testing has been to estimate the capacity of the individual to utilize military education, some of the subtests can be used in the estimation of verbal and logical inductive intelligence (two tests) and spatial ability (one test) at about 20 years of age, i.e., prior to any pertinent exposure to solvents. About half of the subjects in both groups in this study had entered the military service after 1943 and their test results were available for the estimation of preexposure capacity. The mean score of the painter group was not found to be lower than that of the reference group; in fact the painters' scores were somewhat (but not significantly) better.

In Sweden there is a registration of people suffering from alcoholism with social complications. The number of sub- 
jects from the painter and reference groups registered there were found to be four and five, respectively. Nor were there any differences between the groups with respect to brain injuries, episodes of unconsciousness or alcohol consumption as reported in the interview, but the referents were found to smoke more than the painters (table 2).

\section{Health interview and medical examination}

The health interview revealed that eczema and experiences of impaired memory were significantly more frequent among the painters than among the referents. There was also an overrepresentation of diffuse chest pain, extreme fatigue, and

Table 3. Means and standard deviations of the psychological tests for the painter and reference groups.

\begin{tabular}{|c|c|c|c|c|c|c|c|}
\hline \multirow[t]{2}{*}{ Tesit } & \multirow{2}{*}{$\begin{array}{l}\text { Intellectual } \\
\text { function mea- } \\
\text { sured by the } \\
\text { test }\end{array}$} & \multirow[t]{2}{*}{ References } & \multicolumn{2}{|c|}{$\begin{array}{l}\text { Painters } \\
(\mathrm{n}=52)\end{array}$} & \multicolumn{2}{|c|}{$\begin{array}{c}\text { Referents } \\
(\mathrm{n}=52)\end{array}$} & \multirow{2}{*}{$\begin{array}{l}\text { Two-tailed } \\
\text { p vailues } \\
\text { from } \\
\text { Student's } \\
\text { t-test }\end{array}$} \\
\hline & & & Mean & $\mathrm{SD}$ & Mean & $\mathrm{SD}$ & \\
\hline Synonyms & $\begin{array}{l}\text { verbal ability } \\
\text { (vocabulary) }\end{array}$ & Dureman et al. (8) & 18.0 & 6.5 & 16.3 & 6.4 & 0.14 \\
\hline $\begin{array}{l}\text { Figure } \\
\text { Classification }\end{array}$ & $\begin{array}{l}\text { visual-logical } \\
\text { ability }\end{array}$ & $\begin{array}{l}\text { Dureman et al (8), } \\
\text { based on Thur- } \\
\text { stone's primary } \\
\text { mental abilities } \\
(22)\end{array}$ & 17.2 & 4.5 & 19.0 & 3.8 & 0.03 \\
\hline Block Design & spatial ability & $\begin{array}{l}\text { Dureman et al. (8), } \\
\text { identical with Koh's } \\
\text { test in the Wechs- } \\
\text { ler Adult Initelli- } \\
\text { gence Scale (23) }\end{array}$ & 22.2 & 6.5 & 21.2 & 6.1 & 0.43 \\
\hline $\begin{array}{l}\text { Figure } \\
\text { Identification }\end{array}$ & $\begin{array}{l}\text { vigilance, per- } \\
\text { ceptual speed }\end{array}$ & $\begin{array}{l}\text { Dureman et al. (8), } \\
\text { based on Thur- } \\
\text { stone's primary } \\
\text { mental abilities } \\
\text { (22) }\end{array}$ & 28.5 & 9.9 & 27.3 & 7.1 & 0.49 \\
\hline Rivet Test & $\begin{array}{l}\text { psychomotor } \\
\text { coordination }\end{array}$ & Dureman et al. (8) & 156.8 & 27.9 & 144.5 & 29.5 & 0.03 \\
\hline $\begin{array}{l}\text { Konzentrations- } \\
\text { Verlaufs-Test }\end{array}$ & vigilance & Abels (1) & 95.8 & 9.5 & 97.5 & 9.8 & 0.38 \\
\hline $\begin{array}{l}\text { Claeson-Dahls } \\
\text { Learning Test }\end{array}$ & $\begin{array}{l}\text { learning } \\
\text { capacity }\end{array}$ & $\begin{array}{l}\text { Claeson et al. (6) } \\
\text { and Luria (18) }\end{array}$ & 158.7 & 73.9 & 173.9 & 63.5 & 0.26 \\
\hline $\begin{array}{l}\text { Revised Visual } \\
\text { Retention Test }\end{array}$ & $\begin{array}{l}\text { visual reten- } \\
\text { tion }\end{array}$ & Benton (3) & 5.7 & 1.6 & 5.9 & 1.8 & 0.42 \\
\hline $\begin{array}{l}\text { Simple Re- } \\
\text { action Time }\end{array}$ & & & 0.32 & 0.08 & 0.33 & 0.07 & 0.57 \\
\hline $\begin{array}{l}\text { Choice Re- } \\
\text { action Time }\end{array}$ & & & 0.48 & 0.06 & 0.47 & 0.06 & 0.18 \\
\hline $\begin{array}{l}\text { Mirror Tracing } \\
\text { (total time) }\end{array}$ & $\begin{array}{l}\text { sensorimotor } \\
\text { coordination }\end{array}$ & $\begin{array}{l}\text { Dureman et al. (9), } \\
\text { modification of } \\
\text { Starch's Mirror } \\
\text { Drawing Test }\end{array}$ & 83.3 & 41.7 & 82.0 & 32.2 & 0.87 \\
\hline $\begin{array}{l}\text { Mirror Tracing } \\
\text { (error time) }\end{array}$ & $\begin{array}{l}\text { sensorimotor } \\
\text { coordination }\end{array}$ & $\begin{array}{l}\text { Dureman et al. (9), } \\
\text { modification of } \\
\text { Starch's Mirror } \\
\text { Drawing Test }\end{array}$ & 20.4 & 14.0 & 19.3 & 12.9 & 0.70 \\
\hline
\end{tabular}


longer periods of sick leave among the painters [for further details the reader should consult the report by Blume (4)]. In the medical examination the only significant difference found between the groups was a higher hemoglobin concentration in the reference group (table 1). The smoking habits (table 2) cannot explain the differences found in hemoglobin concentration (15). No painter suffered from clinical anemia, but the difference in the mean hemaglobin concentration might indicate an effect of exposure.

\section{Psychological tests}

The mean of each variable for the painter and reference groups is presented in table 3 . Since some of the test scores are inversely related to the performances, the results are possibly more clearly illustrated in fig. 1 , in which the scores have been transformed to a standard scale. The painters were found to have significantly $(p<0.05)$ lower mean performances on the visual/logical and psychomotor tests.

The scores on the psychomotor test and the visual/logical test were transferred into a uniform scale (mean 5, SD 2) by means of the age-adjusted norms given in the manual (8). The differences between the test results and the expected values derived from the verbal test were assumed to reflect the degree of impairment in the measured psychological function; they were calculated for each individual. The means of these differences differed significantly between the groups as shown in table 4. Also on the visual retention test the expected score, as given by the manual with regard to the result on the verbal test and age, was compared with the observed score. As shown in table 4 the mean of the deviations from the expected values among the exposed was significantly greater than that of the reference group, and this result indicates an impaired memory function. Although neither the simple reaction time (a single visual stimulation) nor the choice reaction

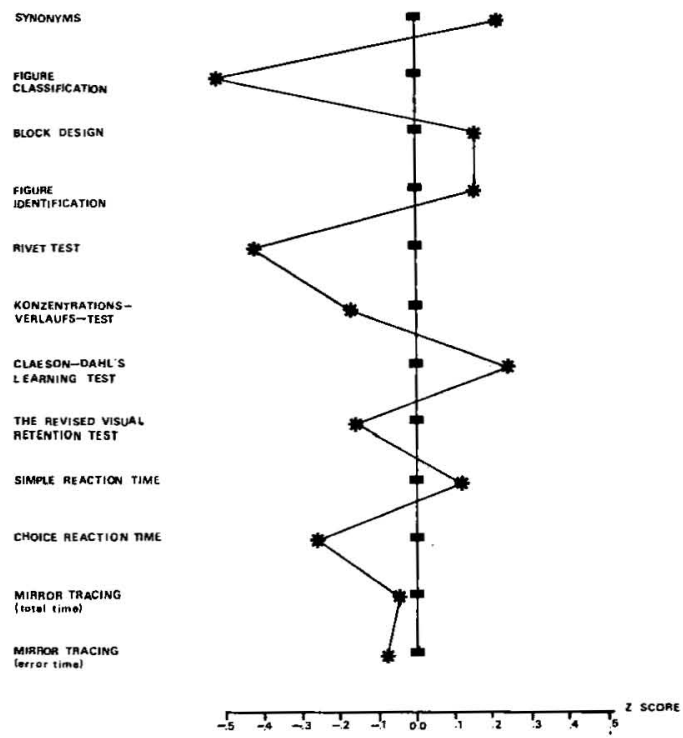

Fig. 1. Deviations of the means of the psychological tests of the painter group from those of the reference group, expressed in terms of standard deviations, i.e., as $\mathrm{Z}$ scores. A Z score with a negative sign indicates an inferior performance for the painiters and a $\mathrm{Z}$ score with a positive sign indicates the reverse.

Table 4. Means of indicators of function change for the painter and reference groups.

\begin{tabular}{|c|c|c|c|}
\hline \multirow{2}{*}{ Variable } & \multicolumn{2}{|c|}{$\begin{array}{l}\text { Mean of individual deviation } \\
\text { from expected value }\end{array}$} & \multirow{2}{*}{$\begin{array}{l}\text { One-tailed } p \\
\text { value from } \\
\text { Student's t-test }\end{array}$} \\
\hline & $\begin{array}{l}\text { Painters } \\
\mathrm{n}=52\end{array}$ & $\begin{array}{l}\text { Referents } \\
n=52\end{array}$ & \\
\hline $\begin{array}{l}\text { Figure Classification (visual-logical } \\
\text { ability) } \\
\text { Rivet Test }\end{array}$ & -0.0 & -1.1 & $\mathrm{p}<0.01$ \\
\hline (pisychomotor coordination) & -0.9 & -2.0 & $0.01<\mathrm{p}<0.05$ \\
\hline Revised Visual Retention Test & 1.5 & 0.9 & $0.01<\mathrm{p}<0.05$ \\
\hline Choice Reaction Time & 16 & 14 & $0.01<\mathrm{p}<0.05$ \\
\hline
\end{tabular}


time (a complex visual stimulaton) differed significantly between the groups, the mean of the individual differences between simple and choice reaction time was significantly greater for the painters than for the referents. Taking this difference is in accordance with the clinical practice of using reaction time measurements in the diagnosis of organic brain dysfunction, a practice which is based on the assumption that diffuse brain damage affects responses to more complex stimuli before it affects responses to simpler ones (16).

\section{Multiple discriminant analysis}

As shown in table 5, the four indicators of function change are intercorrelated, and it might be conceivable that some kind of aggregation of these variables would in-

Table 5. Initercorrelations between indicators of function change, age, occupational years and "painter years" for the painters $(n=52)$.

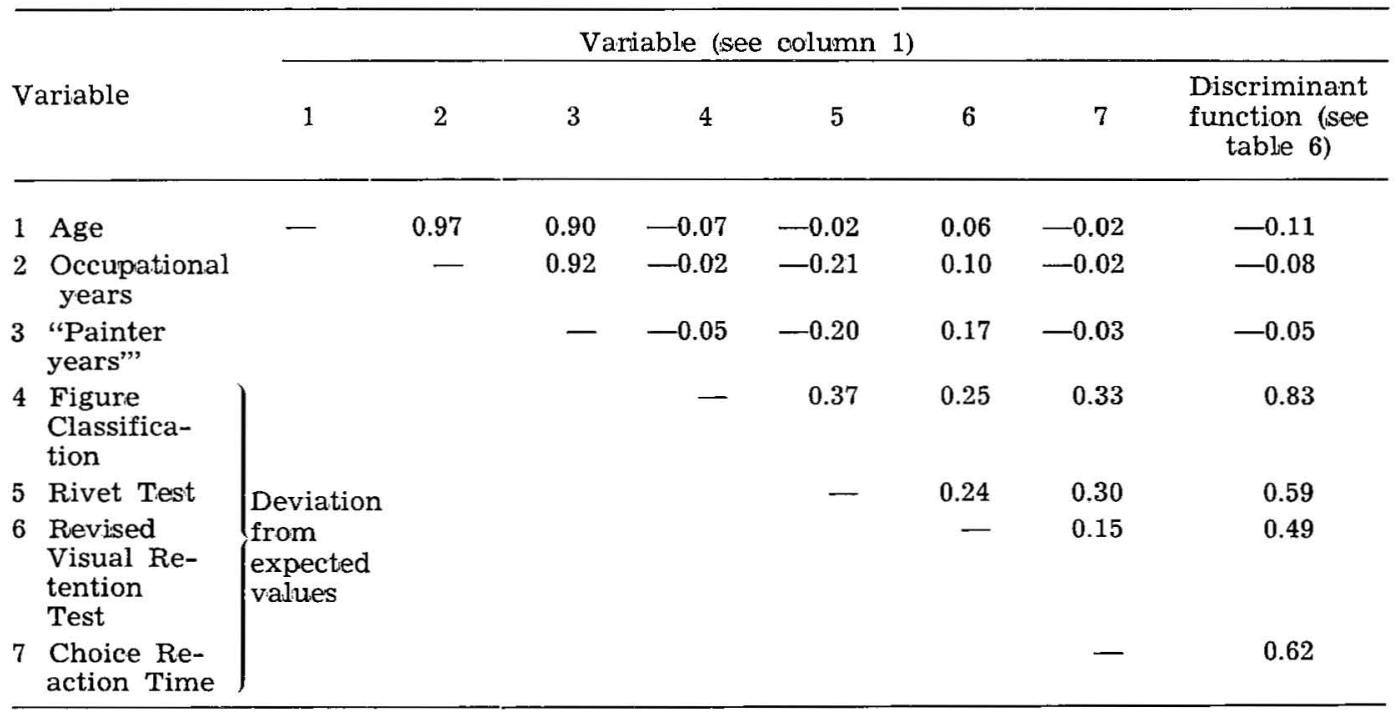

Table 6. Multiple discriminant analysis.

\begin{tabular}{|c|c|c|c|}
\hline Step number & $\begin{array}{l}\text { Variable added, } \\
\text { deviation from } \\
\text { expected values }\end{array}$ & $\begin{array}{l}\text { Point biserial cor- } \\
\text { nelation between the } \\
\text { discriminant function } \\
\text { and the dichotomus } \\
\text { exposure variable } \\
\text { (exposed vs. non- } \\
\text { exposed) }\end{array}$ & Equation \\
\hline 1 & $\begin{array}{l}\text { Figure Classifi- } \\
\text { cation }\left(\mathrm{X}_{1}\right)\end{array}$ & 0.29 & $\mathrm{y}^{\prime}=0.081 * \mathrm{x}_{1}+0.546$ \\
\hline 2 & $\begin{array}{l}\text { Choice Reaction } \\
\text { Time }\left(\mathrm{X}_{2}\right)\end{array}$ & 0.32 & $y^{\prime}=0.073 * x_{1}+0.012 * x_{2}+0.367$ \\
\hline 3 & Rivet test $\left(\mathrm{X}_{3}\right)$ & 0.34 & $\begin{aligned} y^{\prime}= & 0.055 * x_{1}+0.012 * x_{2}+0.026 * \\
& x_{3}+0.381\end{aligned}$ \\
\hline 4 & $\begin{array}{l}\text { Revised Visual Re- } \\
\text { tention Test }\left(\mathrm{X}_{4}\right)\end{array}$ & 0.35 & $\begin{aligned} y^{\prime}= & 0.048 * x_{1}+0.012 * x_{2}+0.025 * \\
& x_{3}+0.022 * X_{4}+0.350\end{aligned}$ \\
\hline
\end{tabular}




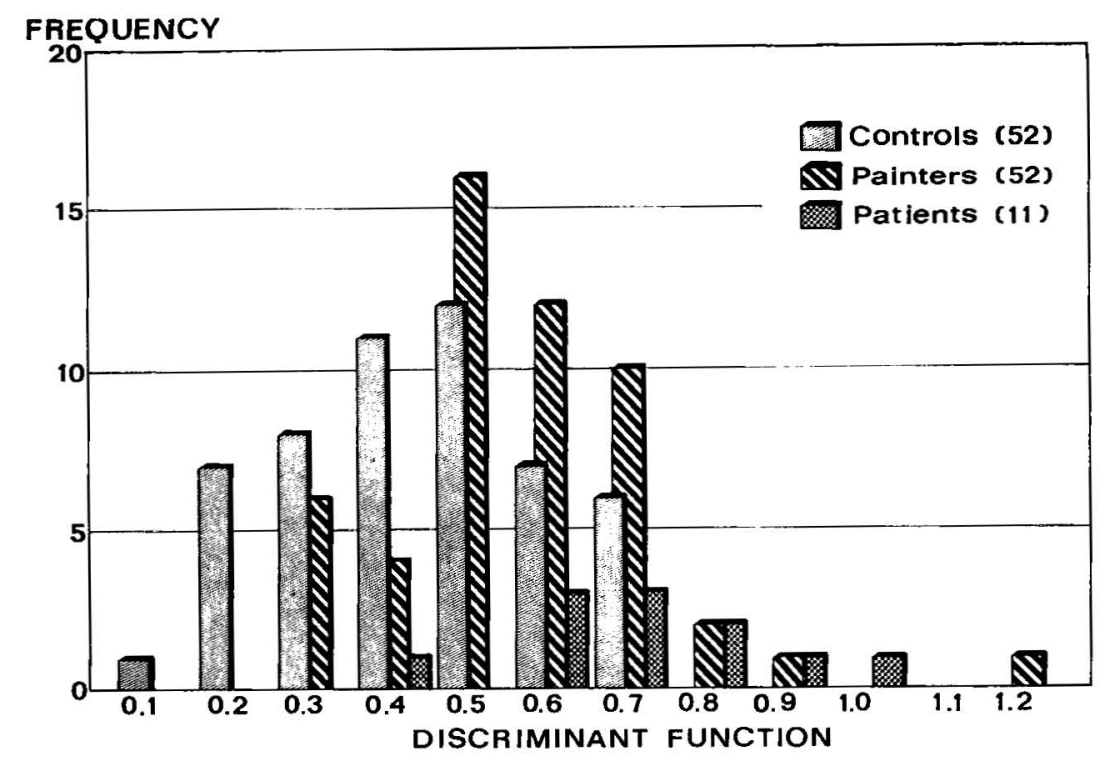

Fig. 2. Distribution of the discriminant functions of the painters, the controls (reference group) and a small sample of patients with clinical signs of brain dysfunction.

crease the correlation between the degree of intellectual impairment and exposure. Therefore, a stepwise multiple discriminant analysis was undertaken which resulted in the equations shown in table 6 . A point biserial correlation of 0.35 was obtained between the weighted sum of these variables and the dichotomous exposure variable defined by group affinity for this sample. Thus, this discriminant function can be regarded as a measure of intellectual impairment and it is therefore helpful when effects on individual patients are considered. However, within the painter group, no correlation was found between the measures of exposure, i.e., occupational years and "painter years," and the effect (table 5).

\section{Diagnostic validity of applied tests}

An evaluation of the diagnostic validity of the discriminant function requires testing a new sample for which either the degree of brain damage is known or, if the assumption of a linear correlation between the degree of exposure and functional disturbances is accepted, the ex- posure history is well known. Finding such a sample is difficult, but obviously some kind of validity analysis is necessary if the difference found between exposed and nonexposed subjects is to have any implications for diagnostic procedures in clinical practice.

For the purpose of validating the discriminant function another body of data was available, namely, 11 clinical patients that had been referred to a psychologist because they showed symptoms attributable to brain dysfunction (19). They were 39 to 62 years of age, most of them above 55. All of them had been exposed to solvents (25-45 years) and most of them were painters. For some individuals a few of the tests included in the discriminant function had been omitted, but in these cases the mean score of the active painters replaced the missing test result. The distribution for the patient group in the discriminant function is presented in fig. 2, which also shows that the clinical patients tended to get higher values in the discriminant function than the active painters, a finding which supports the usefulness of this discriminant function for diagnostic purposes. 


\section{DISCUSSION}

The house painters who consulted the Clinic of Occupational Medicine showed symptoms of memory impairment, fatigue, and personality changes of an asthenic or depressive type which were in fairly good agreement with the "chronic psychoorganic syndrome" according to MayerGross et al. (19). Case reports indicating similar effects of solvents can be found in the literature (5), but there are very few epidemiologic studies on nonacute effects. Hänninen (12) and Lindström (17) however showed that there might be such an effect, and the present investigation is consistent with these earlier reports.

As the testing took place more than $15 \mathrm{~h}$ after exposure, the effects found are either chronic or subchronic. It is conceivable however that the impairment has a chronic character in view of previous reports and another study we have completed (2). Thus, a case-referent study based on a regional disability pension register indicated a risk ratio of $1.8(95 \%$ confidence interval 1.0-3.2) for the possibility of workers exposed to solvents falling ill with neuropsychiatric diseases in comparison to the same possibility for other skilled workers not so exposed. In that study the diagnoses dementia senilis et presenilis and "nervositas" occurred frequently among the exposed. Husman et al. (14) found lower mean performances for a group of car painters than for a reference group in a study with a design similar to ours. Götell et al. (11) and later Gamberale et al. (10) reported prolonged reaction times among workers exposed to styrene even $16 \mathrm{~h}$ after exposure. Thus a number of studies have shown subchronic and chronic effects of solvents on the central nervous system although the solvent concentrations which caused these effects are more or less unknown. Therefore field studies of prevailing exposures to soivents and other agents in painting operations are desirable. There is also a need to study more closely the relations between the degree of exposure and intellectual impairment, both with regard to measures of exposure (e.g., time-concentration products, frequent peak concentrations, etc.) and possible modifiers of effect, such as age, individual susceptibility, and interactions with other pertinent exposures, e.g., alcohol and medicines.

\section{ACKNOWLEDGMENTS}

This investigation was supported by Arbetarskyddsfonden (The Swedish Workers' Protection Fund) grant 125/73.

\section{REFERENCES}

1. ABELS D. Konzentrations-Verlaufs-Test. Verlag für Psychologie, Göttingen 1965, $27 \mathrm{p}$.

2. AXELSON, O., HANE, M. and HOGSTEDT, C. A case-referent study on neuropsychiatric disorder's among workens exposed to solvents. Scand. j. work environ. \& health 2 (1976) 14-20

3. BENTON, A. The revised visual retention test. The State University of Iowa, Iowa City, Iowa 1963. $92 \mathrm{p}$.

4. BLUME, J. Psykiska funktionsförändringar hos byggnadsmålare [Psychological function changes among house painters]. Uppsala Univensitet, Psykologiska Institutionen 1974 (mimeograph).

5. BROWNING, E. Toxicity and metabolism of industrial solvents. Elsevier Publishing Co., Amsterdam 1965. 739 p.

6. CLAESON, L., ESBJORNSSON, E., CARLE, B. and WAHLBIN, M. Claeson-Dahls inlärningstest för kliniskt bruk [ClaesonDahl's learning test for clinical use]. Skandinaviska Testförlaget, Stockholm 1971. $42 \mathrm{p}$.

7. COOLEY, W. and LOHNES, P. Multivariate procedures for the behavioural sciences. John Wiley, New York, N.Y. 1962 $42 \mathrm{p}$.

8. DUREMAN, I., KEBBON, L. and ÖSTERBERG, E. Manual till DS-batteriet. [Manual to the DS-battery]. Skandinaviska Testförlaget, Stockholm 1971. $140 \mathrm{p}$.

9. DUREMAN, I., SÄLDE, H. and ÖSTERBERG, E. Mirror tracing as a diagnostic device for the study of emotional overneactions as adaptive self-control. Psychology laboratory, Department of Psychiatry, Uppisala 1958. (mimeograph).

10. GAMBERALE, F., LISPER, H. and ANSHELM-OLSON, B. Styrengasers effekt på reaktionsförmåga hos arbetare $i$ plastbåtsindustri [The effect of exposure to styrene on reaction time among workers in plastic boat industries] (Arbete och Hälsa no. 8). Arbetarskyddsverket, Stockholm 1975. 23 p.

11. GÖTELL, P., AXELSON, O. and LINDELÖF, B. Field studies on human styrene exposure. Work-environ.-health 9 (1972) $76-83$.

12. HÄNNINEN, H. Psychological picture of manifest and latent carbon disulphide poisoning. Br. j. ind. med. 28 (1971) $374-$ 381. 
13. HALLIN, N. Arbetshygieniska problem vid maleriarbete [Occupational hygienic problems in painting]. Byggförlaget, Stockholm 1975. $23 \mathrm{p}$.

14. HUSMAN, K., SEPPÄLÄINEN, A., KARLI, P., HERNBERG, S. and ESKELINEN. L. The neurological and psychic effect of solvents on car painters. In: Abstracts from the XVIII international congress on occupational health, Brighton, England 14 -19 Sept. 1975. p. 496.

15. ISAGER, H. and HAGERUP, L. Relationship between eigarette smoking and high packed cell volume and hemoglobin levels. Scand. $j$. haematol. 8 (1971) 241-244.

16. KLEBANOFF, S., SINGER, J. and WILLENSKI, H. Psychological consequences of brain lesions and ablations. Psychol. bull. 51 (1954) $1-41$.

17. LINDSTRÖM, K. Psychological performances of workers exposed to various solvents. Work-environ.-health 10 (1973) 1.51155.

18. LURIA, A. Higher cortical functions in man. Basic Books Inc., Publishers Consultants Bureau, New York, N.Y. 1966. $513 \mathrm{p}$.

Received for publication: 1977-02-07
19. MAYER-GROSS, W., SLATER, E. and ROTH, M. Clinical psychiatry (Third edition). Baillière, Tindall \& Cassel, London 1969. $904 \mathrm{p}$.

20. MÜNCHINGER, R. Der Nachweis Zentralnervöser Stönungen bei Lösungsmittelexponierten Arbeitern. In: Proceedings of the international congress of occupational health, Madrid 1963. pp. 687-689.

21. SCHALLING, D. and CRONHOLM, B. "Resistensen" hos ordförrådstest och deras användbarhet vid bedömning av intellektuell reduktion ["Resistance" of vocabulary tiests and their usefulness in diagnosing intellectual reduction]. Nord. psykiatr. tids. (1967) 299-305.

22. THURSTONE, L. Primary mental abilities (Psychometric monographs 1). University of Chicago Press, Chicago, Ill. 1938. 121 p.

23. WECHSLER, D. Manual for Wechsler Adult Intelligence Scale. Psychology Corporation, New York, N.Y. 1955. 110 p.

24. ZIMIMERMAN, I. and WOO-SAM, J. Clinical interpretation of the Wechsler Adult Intelligence Scale. Grune and Stratton, New York, N.Y. 1973. 221 p. 